\title{
Application of anoxic phase in SBR reactor to increase the efficiency of ammonia removal in Vietnamese municipal WWTPs
}

\author{
Tran Ha Quan* and Elena Gogina \\ Moscow State University of Civil Engineering, Yaroslavskoe shosse, 26, Moscow, 129337, Russia
}

\begin{abstract}
Process removal nutrients, especially nitrogen - ammonia in municipal wastewater treatment is a challenger of design and operate wastewater treatment plant. Nowadays in Vietnam, technology SBR has been wide applied in biological wastewater treatment but the concentration of nitrogen - ammonia in treated water cannot achieve the discharge standard. For the purpose to reach the Vietnamese Standard A, the modification of SBR has been added the anoxic phase into operated cycle to create the denitrification's environment and enhance performance of ammonia - nitrogen removal in municipal wastewater treatment at present and in the near future. The results of experiment shows that, the efficiency of $\mathrm{N}-\mathrm{NH}_{4}$ removal in reactors sustainable in range $75-80 \%$ with the nitrogen loadings rate from $0.07-0.25 \mathrm{~kg} \mathrm{~N}-\mathrm{NH}_{4} / \mathrm{kg}$ sludge/d. However, in 3 hours of anoxic phase, the value of specific denitrification rate is 0.10 $-0.15 \mathrm{~kg} \mathrm{~N}-\mathrm{NO}_{3} / \mathrm{kg}$ sludge/d with the organic loadings rate in range 0.3 - $1.0 \mathrm{~kg} \mathrm{BOD} / \mathrm{kg}$ sludge $/ \mathrm{d}$ and can reach the maximum is $0.2 \mathrm{~kg} \mathrm{~N}$ $\mathrm{NO}_{3} / \mathrm{kg}$ sludge $/ \mathrm{d}$ when the organic loadings rate increase to $2.0 \mathrm{~kg} \mathrm{BOD} / \mathrm{kg}$ sludge/d.
\end{abstract}

\section{Introduce}

Removing nutrients in wastewater treatment plants (WWTP), especially ammonia nitrogen is a major challenge in the design of wastewater treatment systems because of their damaged on environment, public health, and economic concerns. For example, more than $0.05 \mathrm{mg} / \mathrm{l}$ of inorganic nitrogen may stimulate algae growth in surface water or more than $0.2 \mathrm{mg} / \mathrm{l}$ of free ammonia may cause acute toxicity to certain species of fish [1].

In biological wastewater process with activated sludge, ammonia removal is accomplished through nitrifying bacteria, called Nitrifiers such as Nitrosomonas and Nitrobacter, which oxidize ammonia to nitrite and then to nitrate. However, the amount of ammonia removal are limited by the organic removal with $5.0 \mathrm{mg}$ nitrogen has been removed per $100 \mathrm{mg}$ BOD in wastewater. So the process denitrification has been applied to reduce concentration of Nitrate to Nitrogen gas [2]. The following equations illustrate each process:

\footnotetext{
* Corresponding author: haquan.891300@gmail.com
} 


$$
\begin{gathered}
\mathrm{NH}_{4}^{+} \stackrel{\text { Nitrifers }}{\longrightarrow} \mathrm{NO}_{3}^{-}+2 \mathrm{H}^{+}+\mathrm{H}_{2} \mathrm{O} \\
\mathrm{NO}_{3}^{-}+\text {carbon source } \stackrel{\text { Bacterial }}{\longrightarrow} \mathrm{N}_{2}+\mathrm{CO}_{2}+\mathrm{H}_{2} \mathrm{O}+\mathrm{OH}^{-}+\text {new cells }
\end{gathered}
$$

By the Nitrogen cycle in nature, denitrification can take place in terrestrial or marine ecosystems. But in the biological wastewater treatment with activated sludge, denitrification occurs in anoxic environments, when the concentration of dissolved oxygen in range $0.2-2.0 \mathrm{mg} / \mathrm{l}$ and the Oxidation - Reduction Potential (ORP) from -200 to 200 $\mathrm{mV}$ in the reactor/tank. Opposed to denitrification, the nitrification with amount of ammonia removal is proportional to concentration of dissolved oxygen in reactors and ORP higher than $200 \mathrm{mV}$ [2,3]. Therefore, in the Conventional activated sludge treatment system, each process divided into each tank with modifications like Ludzack - Ettinger Process and Anoxic Step Feed [1,3].

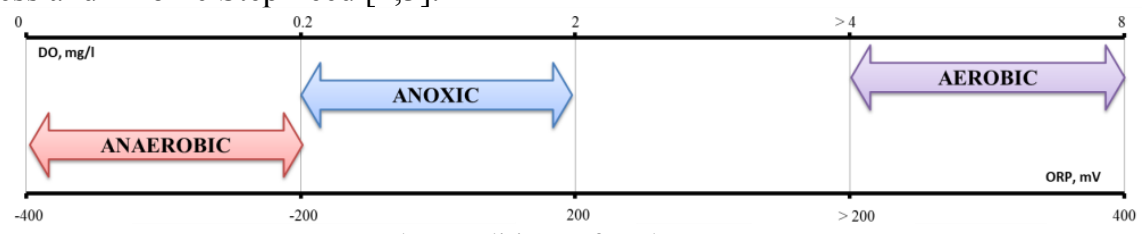

The conditions of each process

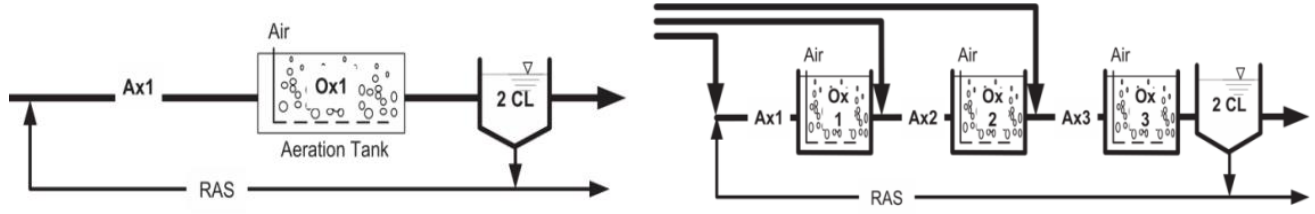

Ludzack - Ettinger Process and Anoxic Step Feed,

Source: Biological nutrient removal Operation in Wastewater treatment plants [1]

Fig. 1. Conditions and application of Anoxic phase in biological wastewater treatment

Nowadays, a variation of activated sludge, the Sequencing Batch Reactors (SBR) has been wide applied for Vietnamese municipal wastewater treatment [4]. With the advantages about suitable for Vietnamese conditions such as easy control the treatment process in the wide range of pollutants, affected by tropical climate, or economic efficiency through reconstructed aerotank and saving electric - land using [5,6,7], more than $60 \%$ projects of urban WWTP in Vietnam with the capacity higher than $30,000 \mathrm{~m}^{3} / \mathrm{d}$ was SBR. However, the performance of them was not good and will be decreased when the capacity increasing in the near future. After that, the concentration of nutrients cannot achieve the discharge standard (Standard A of Vietnam) [8], because efficiency of nutrification and nutrient removal does not reach the design value [9].

For increasing the efficiency of ammonia removal in the SBR, the experiment with model of SBR reactor has been performed at laboratory Biological Wastewater treatment, Environment Protect Research Centre, Danang University to determine the efficiency of nitrogen transform process with Vietnamese municipal wastewater at present and near future.

\section{Materials and methods}

Most cities in Vietnam have a combined sewerage system, where drainage and municipal wastewater have been mixed and pumped to the WWTP. In the Vietnamese municipal wastewater, the concentration of organic matters, calculated by $\mathrm{BOD}_{5}$ in range $75-100$ 
$\mathrm{mg} / \mathrm{l}$; and the concentrations of nutrients with nitrogen - ammonia is $20-35 \mathrm{mg} / \mathrm{l}$ and with Total Kjeldahl Nitrogen (TKN) is $50-80 \mathrm{mg} / \mathrm{l}$. At present, when the WWTP only operates a half of design values, the efficiency in SBR for organic matters is $80-90 \%$ but for nutrification and nutrient removal varies from $30-50 \%$ for Nitrogen. However, the concentration of ammonia in treated water in most municipal wastewater treatment plants cannot reach the Vietnamese discharge standard - The Standard A. The details of parameters, including the influent, effluent and The Standard A have been showed and compared in Table $1[9,10]$.

Table 1. The parameters of Vietnamese municipal wastewater

\begin{tabular}{|c|c|c|c|}
\hline Parameter & Influent of WWTP & Effluent of SBR WWTP & Standard A \\
\hline $\mathrm{BOD}, \mathrm{mg} / \mathrm{l}$ & $75-100$ & $10-15$ & 30 \\
\hline $\mathrm{COD}, \mathrm{mg} / \mathrm{l}$ & $150-300$ & $20-40$ & 50 \\
\hline $\mathrm{N}-\mathrm{NH}, \mathrm{mg} / \mathrm{l}$ & $20-30$ & $5-10$ & 5 \\
\hline $\mathrm{N}-\mathrm{NO}_{3}, \mathrm{mg} / 1$ & $0-0.5$ & $25-30$ & 30 \\
\hline $\mathrm{TKN}, \mathrm{mg} / \mathrm{l}$ & $50-80$ & $20-25$ & - \\
\hline
\end{tabular}

For purpose of creation the denitrification's environments, the SBR model in laboratory simulates the Vietnamese WWTP with some additional installation, including stirrer and lid - reactor. The scheme and operation cycle of model and has been showed in the Figure below [1,11]:

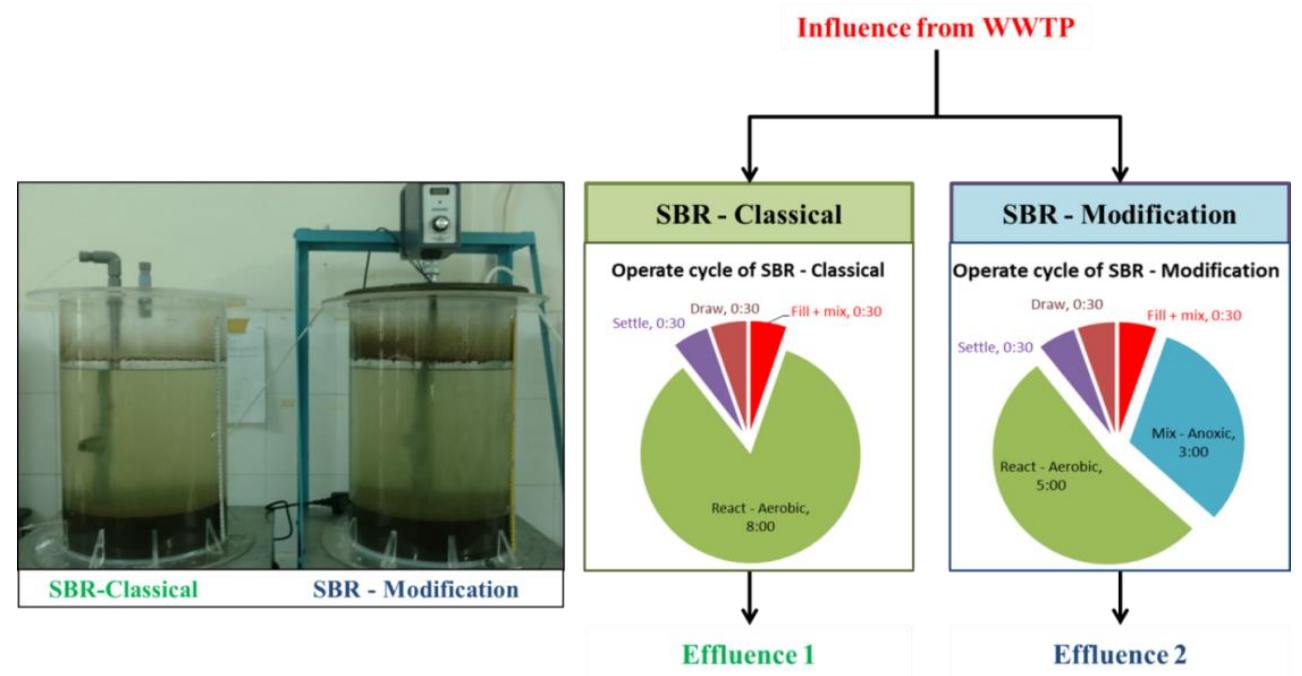

Fig. 2. The SBR model in laboratory

The experiment site has been divided in 2 steps, corresponding to Vietnamese municipal wastewater at present and in the future, when the concentration of pollutants increases 2 times. The volume of each reactor is 40 litres, with the percentage of sludge at beginning is $20 \%$ and parallel operated and treated 25 litres municipal wastewater, taken from Vietnamese WWTP. The efficiency of ammonia removal of SBR model with denitrification is determined when comparing the quality of treated water of each reactors, 
including concentration of organic matters and nutrient: $\mathrm{BOD}_{5}, \mathrm{COD}, \mathrm{N}-\mathrm{NH}_{4}, \mathrm{~N}-\mathrm{NO}_{3}$, TKN and the sludge's parameters.

In the anoxic phase of reactor SBR - Modification, the quantity and efficiency of Nitrate removal characteristic by the specific denitrification rate and has been determined by equation $[1,2]$ :

Where:

$$
S D N R=\frac{N O_{3} \times V_{\text {anox }}}{M L V S S}
$$

$S D N R$ - Specific denitrification rate;

$\mathrm{NO}_{3}$ - Nitrate removed;

$V_{\text {anox }}$ - Anoxic tank volume, in this condition is the volume of mode;

$M L V S S$ - Mixed liquor volatile suspended

So it is depending on type of carbon source and amount of carbon available, which measured by the ration Food/Microorganisms or the rate between readily biodegradable $\mathrm{COD}$ and biodegradable COD (rbCOD/bCOD).

Furthermore, the increasing of concentration pollutants in the influent of models has been accessed the efficiency of technology SBR when quality and flow rate of municipal wastewater raise in the near future. All of processes analysing wastewater quality has been conducted at laboratory of EPRC by Standard Methods for the Examination of Water and Wastewater [12].

\section{Results and discussion}

\subsection{Result 1: The biological wastewater treatment}

The quality of effluent of each reactor has been showed in Figure 3:

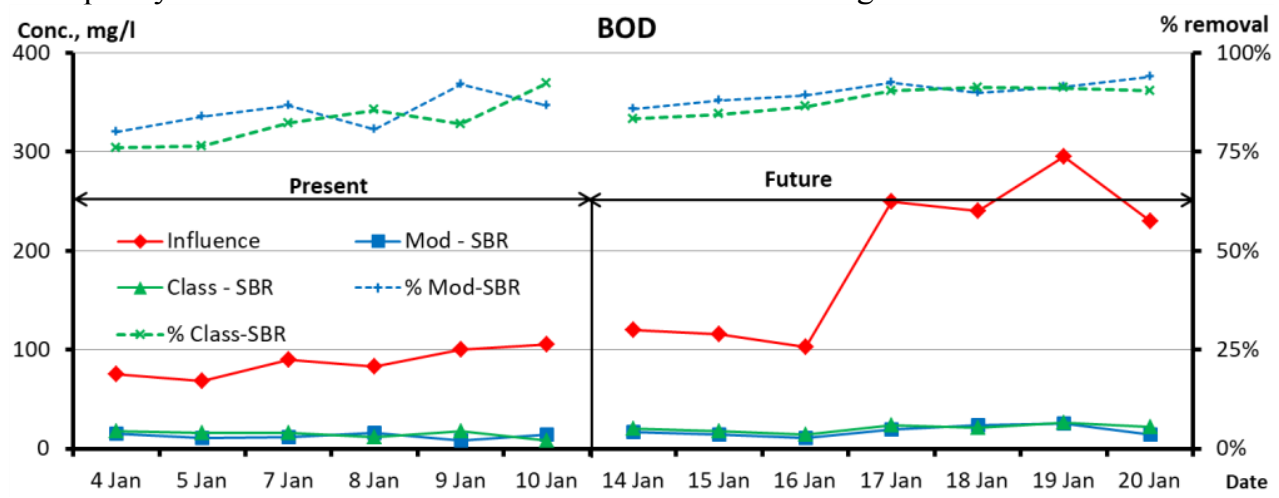



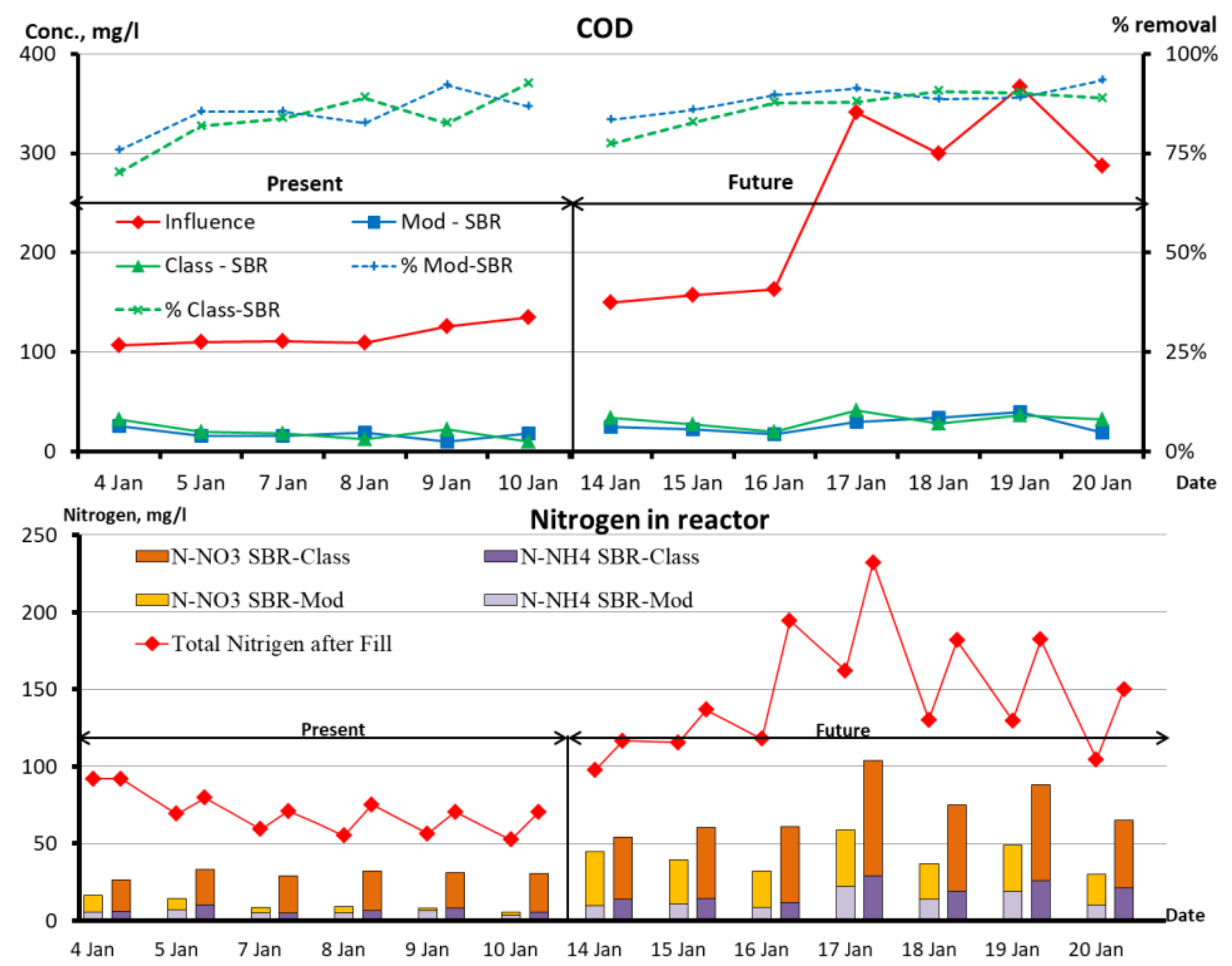

Fig. 3. The concentration of influent, effluent and the performance of model SBR

About the organic matters: The efficiency of BOD and COD removal is sustainable in range $80-90 \%$ with both reactors with all conditions, at present and in the near future. The concentration of them reaches the Vietnamese discharge standard - Standard A.

About Nitrogen removal: When adding 3 hours denitrifers - anoxic, the performance of Nitrogen removal of SBR - Modification always better then Classical $10-20 \%$. The Classical SBR only ensures the treatment at present, and cannot reach the discharge standard when the pollutants in municipal wastewater increases in the future, when the efficiency decreases $20 \%$ for $\mathrm{N}-\mathrm{NH}_{4}$ and $40 \%$ for TKN. With the Modification one, the percentage removal almost unchanged in the conditions of municipal wastewater at present or in the future. Its efficiency sustainable in range $75-80 \%$ and the quality of effluent achieves the Standard A of Vietnam.

The relationship between efficiency of removal ammonia/TKN and the loading rate of each reactor in effluent has been showed in the Figure 4:

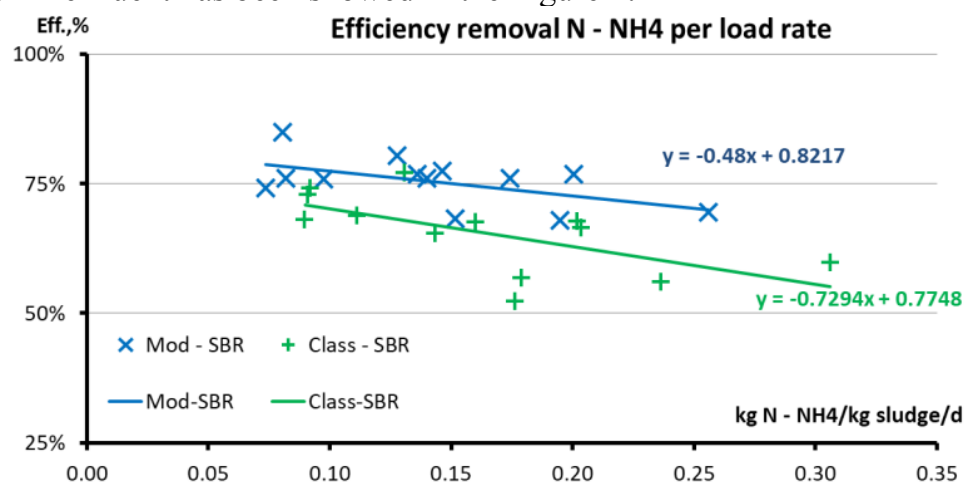




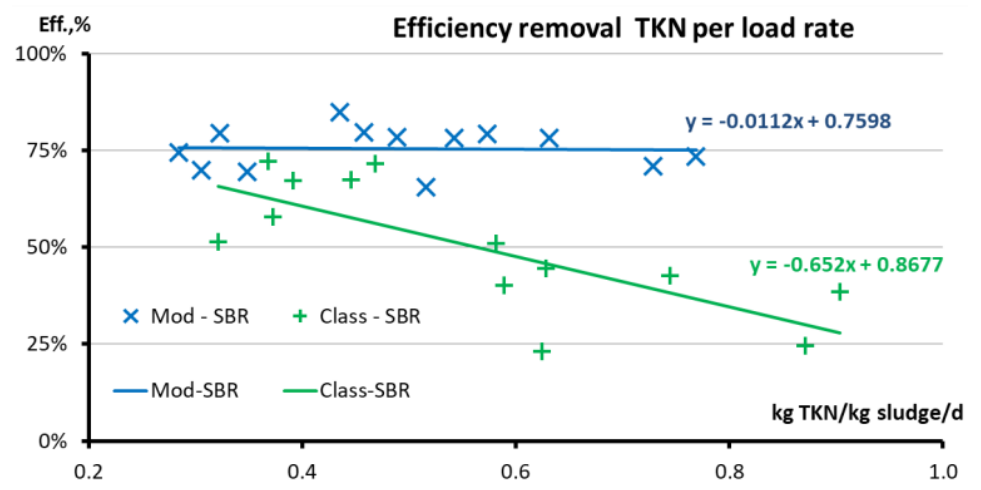

Fig. 4. The relationship between efficiency of removal ammonia/TKN and the loading rate

Basically, the efficiency of nitrogen removal is inversely proportional with the loading to the reactor and the trend line of each process has been showed in the graphic. In the period of Ammonia loading rate $0.07-0.30 \mathrm{~kg} \mathrm{~N}-\mathrm{NH}_{4} / \mathrm{kg}$ sludge/d, the efficiency removal of Classical reactor decreases from $70 \%$ to $50 \%$, but the Modification one only decreases $10 \%$ (from $80 \%$ to $70 \%$ ). At the same compare conditions, in the TKN graphics, the percentage of removal always sustainable in $75 \%$ in Modification SBR because the anoxic phase has been used and transformed all Nitrogen - nitrate to Nitrogen - gas with the loading rate $0.3-0.8 \mathrm{~kg} \mathrm{TKN} / \mathrm{kg}$ sludge $/ \mathrm{d}$. The details of nitrogen transforming has been calculated in the next part of results.

\subsection{Result 2: The denitrification phase in reactor SBR - Modification}

When focus into the denitrification with anoxic/aerobic phase in the reactor SBR Modification, the concentration of Nitrate has been showed in the table 2.

Table 2. Concentration nitrate in model SBR - Modification

\begin{tabular}{|c|c|c|c|c|c|c|c|}
\hline \multicolumn{4}{|c|}{ Step experiment - Present } & \multicolumn{4}{c|}{ Step experiment - Future } \\
\hline Date & After 0h* & After 3h & After 8h & Date & After 0h* & After 3h & After 8h \\
\hline 4 Jan & 0.18 & $\sim 0$ & 11 & 14 Jan & 0.60 & $\sim 0$ & 35 \\
\hline 5 Jan & 2.75 & $\sim 0$ & 7.0 & 15 Jan & 8.75 & 3.4 & 29 \\
\hline 7 Jan & 1.75 & $\sim 0$ & 3.7 & 16 Jan & 7.25 & 2.6 & 24 \\
\hline 8 Jan & 0.92 & $\sim 0$ & 4.0 & 17 Jan & 6.00 & 1.6 & 37 \\
\hline 9 Jan & 1.00 & $\sim 0$ & 1.6 & 18 Jan & 9.25 & 3.3 & 23 \\
\hline 10 Jan & 0.40 & $\sim 0$ & 2.4 & 19 Jan & 5.75 & 1.6 & 30 \\
\hline - & - & - & - & 20 Jan & 7.50 & 2.0 & 20 \\
\hline
\end{tabular}

*Concentration Nitrate after $0 \mathrm{~h}$ is the mixed of Nitrate in influence and the Nitrate in the rest wasted water after draw phase (fraction of wasted water in previous cycle/wastewater in next cycle is 0.2 )

In 3 hours of phase Anoxic - Denitrification of model SBR modifications, in step Present, all of Nitrate has been transformed to Nitrogen - gas and when scaling model to 
the step Future, the concentration of Nitrate decreases $5-6 \mathrm{mg} / \mathrm{l}$. Therefore, when applying the equation of SDNR and compare the results with some standard line in the standard conditions, including temperature is $20^{\circ} \mathrm{C}$ and the fraction of $\mathrm{bsCOD} / \mathrm{bCOD}$ is 10,30 and 50; the values of reactor SBR - Modifications has been showed in the Figure 5.

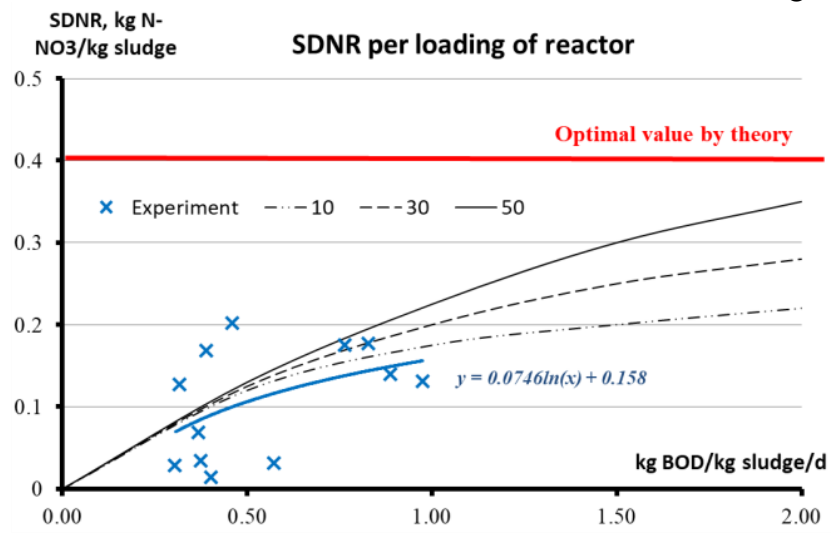

Fig. 5. The SDNR in reactor and base line in Standard conditions

The trend line of SDNR of model is the same characteristic with the line of fraction bsCOD/bCOD by 10 . Through the formula of it, the SDNR of model can reach the maximum value is $0.2 \mathrm{~kg} \mathrm{~N}-\mathrm{NO}_{3} / \mathrm{kg}$ sludge/d when the organic loading increase to $2 \mathrm{~kg}$ $\mathrm{BOD} / \mathrm{kg}$ sludge/d.

\section{Conclusions}

Application anoxic phase in reactor SBR is one of the variant for increasing the efficiency nitrogen and ammonia removal when the flow rate of municipal wastewater raises in the near future. After that, the reactor also ensures the quality of treated water when the concentration of pollutant increases 2 times.

On the other hand, the anoxic phase has complicated conditions, with concentration of dissolved oxygen in range $0.2-2 \mathrm{mg} / \mathrm{l}$ and the Oxidation Reduction Potential from -200 $\mathrm{mV}$ to $200 \mathrm{mV}$. Therefore, it is necessary to research an automatic controllers, which connected to sensors in the full scale model for evaluate the optimal operation mode for technology SBR in Vietnamese WWTP in the near future.

I would like to express my deep gratitude to Dr. Tran Van Quang, students Nguyen Ngoc Phuong and Truong Quoc Dai in the Environment Protect Research Center, Danang University for supporting me during the experiment.

\section{References}

1. Water Environment Federation, American Society of Civil Engineers, Enviromental and Water resource Institute. Biological nutrient removal Operation in Wastewater treatment plants New England interstate water pollution control commission, Manual of Practice No.29. Chapter 22 (2005)

2. Metcalf \& Eddy, Inc. 6. Wastewater engineering treatment and reuse (Fourth Edition)// The McGraw Hill Companies. Chapter 7, 8. (2003) 
3. Michigan Department of Environmental Quality. Nitrification and Denitrification, Operator Training and Certification Unit. Online Training Courses for Municipal \& Industrial Wastewater

4. Elena Gogina, Tran Ha Quan. The assessment of technology SBR in Vietnamese wastewater treatment. Construction The formation of living environment, XXI International Scientific Conference on Advanced In Civil Engineering. MGSU 2018

5. United States Environmental Protection Agency EPA/625/8-86/011. Summary report Sequencing Batch Reactor. (1986)

6. New England interstate water pollution control commission. Sequencing Batch Reactor Design and Operational Considerations, Lowell, MA 01852-1124 (2005)

7. Wilderer P.A. Irvine R.L. Goronszy M.C. Sequencing Batch Reactor, The International water association Publishing. (2001)

8. National technical regulation on domestic wastewater, QCVN 40: 2010/BTNMT/ HaNoi. (2008)

9. The World Bank. Vietnam Urban Wastewater Review Executive Summary, Australian Aid, 30 - 34 (2013)

10. Nguyen Viet Anh. Vietnam water and wastewater report. (2016)

11. Stig Morling. Nitrogen removal efficiency and nitrification rates at the Sequencing batch reactors in Nowy Targ, Poland, Vatten, ISSN 0042-2886, Vol. 64, no 2. 121 128 (2008)

12. American Public Health Association. Standard Methods for the Examination of Water and Wastewater 20th Edition (1998) 